FOLIA PRAFHISTORICA POSNANIENSIA T. XIII/XIV - 2005

INSTYTUT PRAHISTORII, UAM POZNAŃ - ISBN 83-7177-388-9 ISSN 0239-8524

\title{
CASIMIRO SIUCHNIŃSKI IN MEMORIAM
}

\author{
KAZIMIERZ SIUCHNIŃSKI - UCZONY I WYCHOWAWCA
}

KAZIMIERZ SIUCHNIŃSKI - SCHOLAR AND TUTOR

\section{Dobrochna Jankowska}

Instytut Prahistorii, Uniwersytet im. Adama Mickiewicza ul. Św. Marcin 78, 61-809 Poznań, Poland

Artykuły wspomnieniowe, pisane z okazji rocznicy urodzin czy śmierci ludzi nauki konstruowane są zwykle według pewnego kanonu obejmującego najważniejsze dane z życiorysu, najznaczniejsze osiągnięcia naukowe i organizacyjne, wreszcie - próbę oceny roli uczonego $w$ rozwoju uprawianej przez niego dziedziny. Zasada jest redakcja tekstu sugerująca dążenie do maksymalnego obiektywizmu oceny i unikanie refleksji osobistych. W wypadku Kazimierza Siuchnińskiego napisanie takiego wspomnienia nie jest możliwe. Nikt bowiem, kto miał okazję zetknąć się z Nim bliżej, a tym bardziej z Nim pracować, nie potrafi, wspominając go ukryć, nawet po latach, swych emocji!. Jestem winna Jego pamięci tych kilka nieporadnych refleksji, gdyż Kazimierz Siuchniński, jako opiekun mojego rocznika (1962-1967) czuwał nad przebiegiem moich studiów, Jemu glównie, jestem przeświadczona, zawdzięczam asystenturę w ówczesnej Katedrze Archeologii UAM w Poznaniu, On także uczył mnie trudnej sztuki przekazywania wiedzy studentom oraz przekonywał, że nadaję się do pracy naukowej. Jego niezachwiana wiara w moje możliwości pomogła mi dotrwać do doktoratu. Mam wrażenie, że chcąc umożliwić mi zgromadzenie materiałów do tej pracy, co wiązało się z koniecznością pozyskania funduszy, „zwolnil” mi miejsce na Pomorzu Środkowym, rezygnując na kilka lat $\mathrm{z}$ własnych planów działalności terenowej. Jemu więc zawdzięczam, że osiagnęłam cokolwiek w życiu zawodowym.

\footnotetext{
'Por. choćby Ż a k 1983; także Ko c h a now s k i 2005, s. 147-148
} 
Zainteresowania naukowe Kazimierza Siuchnińskiego zarysowały się już w trakcie Jego studiów. Dyplom magisterski uzyskał za opracowanie materiałów z cmentarzyska i osady w Wartin Kr. Randow ${ }^{2}$, datowanych na neolit i wczesną epokę brązu. Materiały te pochodziły z przedwojennych badań niemieckich, a praca nad nimi pozwoliła młodemu badaczowi nabyć doświadczenia w studiach archiwalnych, co stało się w przyszłości Jego specjalnością.

W całej swej dalszej, przeszło dwudziestopięcioletniej karierze Kazimierz Siuchniński poświęcił się wyłącznie studiom nad prahistorią Pomorza, szczególnie Zachodniego i Śodkowego. Jego rzeczywistą pasją był okres neolitu i początki epoki brązu i tej problematyce poświęcone były Jego badania indywidualne. Równocześnie był współzałożycielem zespołu badawczego zajmującego się wczesnośredniowiecznym osadnictwem grodowym na Pomorzu Środkowym. W ramach tego zespołu, w którym znalazł się nie tylko ze względu na możliwość zmierzenia się z fascynującym wyzwaniem naukowym, ale też kierując się względami przyjaźni, uczestniczył w prowadzonych skrupulatnie i metodycznie badaniach weryfikacyjnych grodzisk oraz rejestracji ich bezpośredniego zaplecza osadniczego. Badania te, prowadzone w latach 1962-1972, objęly wszystkie powiaty ówczesnego województwa koszalińskiego oraz dwie tzw. powierzchnie próbne, wytyczone na Pojezierzu Drawskim i Pobrzeżu Słowińskim. Prace te, wzorowane częściowo na wcześniejszych podobnych akcjach W. Kowalenki i W. Hensla w Wielkopolsce ${ }^{3}$ miały jednak na Pomorzu bez wątpienia charakter pionierski, nie tylko ze względu na fakt, że była to pierwsza tego typu planowa, długofalowa akcja, ale i ze względu na nowatorskie założenia metodyczne i zastosowane rozwiązania techniczne (np. metoda wykonywania planów warstwicowych obiektów), dostosowane do skromnych możliwości ekipy. Efektem tych badań - poza cennym katalogiem - było opracowanie typologii grodzisk wczesnośredniowiecznych Pomorza Środkowego ${ }^{4}$, a także zebranie materiałów do studium o środowiskowych uwarunkowaniach osadnictwa wczesnośredniowiecznego w tym regionie ${ }^{5}$. W uczestnictwie K. Siuchnińskiego w fimalizacji tego dużego przedsięwzięcia badawczego przeszkodziła Jego przedwczesna śmierć.

Studia nad neolitem i wczesną epoką brązu prowadzone przez Kazimierza Siuchnińskiego można podzielić na dwa etapy. Pierwszy z nich zapoczątkowany został zaraz po studiach, kiedy młody badacz został zatrudniony w Muzeum Pomorza Zachodniego w Szczecinie, gdzie miał możność zapoznania się ze zgromadzonymi tam zbiorami i bogatym archiwum poniemieckim. Starał się wówczas, przy okazji prowadzenia prac ratowniczych na różnych stanowiskach, prowadzić weryfikację okolicznych, bezpośrednio interesujących go stanowisk (m.in. osady kultury pucharów lejkowatych w Cedyni), co nie zawsze spotykało się z aprobatą zwierzchników.

Po objęciu asystentury w ówczesnej Katedrze Archeologii UAM (1961) Kazimierz Siuchniński stracil bezpośredni dostęp do zbiorów Muzeum Szczecińskiego. Niemniej

\footnotetext{
${ }^{2}$ Siuchniński 1958.

${ }^{3}$ Kowalenko 1938; Hensel 1950.

${ }^{4}$ Olczak, Siuchniński 1976.

${ }^{5}$ Siuchninski 1974.
} 
zgromadzone wcześniej informacje wystarczyły do napisania rozprawy doktorskiej: Klasyfikacja kultur neolitycznych na Pomorzu Zachodnim, która została opublikowana w dwóch częściach, w latach 1969 i 1972 . Praca ta, podsumowująca ówczesny stan wiedzy o neolicie pomorskim, rozpatrywanym przez pryzmat ogólnoeuropejskiej refleksji nad tym okresem, do dziś stanowi podstawowe kompendium źródłowe, bez którego badacz Pomorza nie może się obejść.

Zaangażowanie Kazimierza Siuchnińskiego w prace zespołu do badań grodzisk wczesnośredniowiecznych ograniczyło na pewien czas zakres jego badań własnych. Dopiero w 1975 r. uczony wrócił do realizacji swych planów, organizując spośród swych studentów własną grupę badawczą ${ }^{6}$, z którą w latach 1975-1979 przeprowadził weryfikację stanowisk archiwalnych zaliczanych do wczesnej epoki brązu na terenie Krajny oraz wykopaliska na osadzie grupy ustowskiej kultury pucharów lejkowatych w Szczecinie-Ustowie ${ }^{7}$ oraz na obiektach wczesnobrązowych w Śmiardowie Krajeńskim, Kruszkach i Dworzakowie (Krajna) ${ }^{8}$. W roku 1977, rezygnując, ze względu na przedłużające się studia, z projektu habilitowania się w zakresie wczesnego średniowiecza pomorskiego, przedstawił jako rozprawę habilitacyjną pracę pod tytułem: Stosunki kulturowe u ujścia Odry w neolicie i początkach epoki brazu, która ukazała się drukiem pośmiertnie w formie dwóch obszernych rozdziałów dzieła zbiorowego Dzieje Szczecina ${ }^{9}$. Praca ta zamyka drugi etap Jego studiów nad pradziejami Pomorza. K. Siuchniński zawarł w niej całą swą niezwykle rozległą wiedzę o neolicie i wczesnej epoce brązu, a także bogate doświadczenie z zakresu metodyki studiów osadniczych. Opracowanie to różni się znacznie od napisanego dziesięć lat wcześniej doktoratu sposobem ujęcia i szerokością spojrzenia na problem, dzięki czemu przez pryzmat stosunkowo niewielkiego obszaru ujścia Odry Autor był w stanie odnieść się do kwestii stosunków kulturowych $w$ badanym okresie $w$ całej pojezierno-nadmorskiej strefie południowo-zachodniego Bałtyku. Zawarł też w tej pracy oryginalne hipotezy i postulaty badawcze, które zamierzał zweryfikować w niedalekiej przyszłości. Czynił w tym kierunku przygotowania, których elementem był zwarty i doskonale przygotowany program badań na Pojezierzu Krajeńskim, które badacz uważał za teren kluczowy dla rozwiązania kwestii początków epoki brązu na Pomorzu. Planów tych jednak nie było Mu dane zrealizować.

Dorobek pisarski Kazimierza Siuchnińskiego obejmuje około 60 pozycji ${ }^{10}$. Jego prace można $z$ grubsza podzielić na trzy grupy:

a) drobne, o charakterze materiałowym i sprawozdawczym, w tym liczne notki typu „odkrycia”, pochodzące głównie z wczesnego, ,muzealnego” okresu jego działalności zawodowej;

\footnotetext{
${ }^{6}$ Por. Kukawka 2005, s. 15 n.

${ }^{7}$ S i uchniński 1976a; 1981

${ }^{8}$ S i uchniński 1976b; 1979; 1980

${ }^{9} \mathrm{~S}$ i uchniński 1983a; $1983 \mathrm{~b}$.

${ }^{10} \mathrm{Effertowa} 1983$
} 
b) opracowania źródłowe i artykuły problemowe, pisane często we współautorstwie, dotyczące różnych aspektów osadnictwa grodowego na Pomorzu lub metodyki badań grodzisk;

c) studia nad neolitem i wczesną epoką brązu na Pomorzu.

Dorobek ten, wyłączywszy ostatnią grupę publikacji, gdzie autorytet naukowy Autora jest, jak już wspominano, niekwestionowany, wymyka się jednoznacznej ocenie. Koniecznie trzeba docenić wkład K. Siuchnińskiego w publikowanie źródeł - te prace nigdy nie stracą wartości. Bardzo trudno natomiast ocenić jego udział w każdej z sygnowanych przez niego prac zbiorowych. K. Siuchniński deklarował się jako zwolennik pracy zespołowej. Cechowała Go przy tym absolutna lojalność wobec zespołu. Interesował Go ponadto sam proces badawczy, formułowanie i sprawdzanie hipotez w drodze żywych dyskusji naukowych, natomiast niezbyt dbał o dokumentowanie swych dokonań i przemyśleń na piśmie. Być może uważał, że ma na to jeszcze czas. Ogromna odpowiedzialność za słowo pisane i dbałość o formę publikowanych tekstów, charakteryzująca zresztą nie tylko Jego, ale $i$ inne współpracujące z Nim osoby powoduje, że w tekstach zatarte są indywidualne cechy stylistyki autorów.

W roku 1978 Kazimierz Siuchniński został wybrany na Prodziekana Wydziału Historycznego UAM do spraw studenckich. Na stanowisku tym pozostał do śmierci. Wypadło Mu pełnić tę funkcję w bardzo trudnym okresie narastania w środowisku studenckim nastrojów opozycyjnych i podczas gorących dni zrywu solidarnościowego. Nie wiem, jak dalece K. Siuchniński podzielal poglądy studentów. Nie uciekał jednak od dyskusji z nimi, nieraz bardzo trudnych i ostrych. Starał się także ze wszystkich sił, wykorzystując wszelkie legalne i nielegalne metody, zapewnić konspirującym studentom ochronę i umożliwić im, mimo licznych często brutalnych nacisków zewnętrznych, ukończenie studiów. Niejeden znany obecny polityk wiele mu pod tym względem zawdzięcza. Czynil to jednak bardzo dyskretnie i w takiej formie, że zainteresowani często nie zdawali sobie sprawy, że wlaśnie otrzymują potrzebną pomoc. Przyjaciele, obserwujący wówczas zachowanie K. Siuchnińskiego, nie mają wątpliwości, że to służba na rzecz studentów, za których czuł się odpowiedzialny, i duży stres związany z burzliwymi wydarzeniami lat 80/81 były bezpośrednią przyczyną Jego nagłego i przedwczesnego zgonu.

W chwili śmierci Kazimierz Siuchniński był w przełomowym momencie rozwoju swej kariery naukowej. Uzyskanie habilitacji dawało mu możliwość całkowicie samodzielnego konstruowania programu badawczego, a także kształcenia młodej kadry kilku potencjalnych doktorantów szykowało się do pisania dysertacji pod Jego kierunkiem. Był także naturalnym kandydatem do objęcia w przyszlości funkcji dyrektora Instytutu Prahistorii UAM. Prowadzone dotąd studia wkraczaly w etap finalizacji. Prawdziwe sukcesy miały dopiero nadejść. Nie nadeszły.

Są uczeni, których wielkość wyraża się w ich dorobku pisarskim i tacy, którzy są wielcy poprzez swoich uczniów, których ukształtowali, zainspirowali i pozwolili się im swobodnie rozwijać i iść własną drogą. Pierwsi figurują w encyklopediach, drudzy żyją w ludzkich sercach; jest ich niewielu, ale to właśnie dzięki nim dokonuje się prawdziwy postęp. 


\section{BLIBLIOGRAFIA}

\section{Effertowa J.}

1983 Bibliografia prac Kazimierza Siuchnińskiego, „Sprawozdania Archeologiczne” t. XXXIV, s. 303-305.

Hensel W.

1950 Studia i materiaty do osadnictwa Wielkopolski wczesnohistorycznej, t. 1, Poznań.

Kochanowski M.

2005 Pierwsi rolnicy na Ziemi Kociewskiej-impresja z najnowszych odkryć archeologicznych, „Folia Praehistorica Posnaniensia" XIII/XIV, s. 147-160.

Kowalenko W.

1938 Grody i osadnictwo grodowe Wielkopolski wczesnohistorycznej, Poznan.

Kukawka S

2005 O Kazimierzu Siuchnińskim - wspomnienie po latach, „Folia Praehistorica Posnaniensia” $\mathrm{XIII} / \mathrm{XIV}$, s. $15-21$

Olczak J., Siuchniński K.

1976 Typologia wczesnośredniowiecznych grodzisk Pomorza Środkowego [Rés.: La typologie des enceintes fortifiées du Haut Moyen âge de Poméranie ventrale], „Slavia Antiqua” t. 23, s. 11-152.

Siuchniński K.

1958 Kurhan 60 z cmentarzyska w Wartin, pow. Angermünde (NRD), „Materiały Zachodniopomorskie" t. 2, s. $7-40$.

1969 Klasyfikacja czasowo-przestrzenna kultur neolitycznych na Pomorzu Zachodnim. cz. 1: Katalog źródel archeologicznych, Szczecin

1972 Klasyfikacja czasowo-przestrzenna kultur neolitycznych na Pomorzu Zachodnim, cz. II: Opracowanie analityczne [Zusammenfassung], Szczecin.

1974 Zależności między osadnictwem wczesnośredniowiecznym a głównymi elementami fizyczno-geograficznymi na Pobrzeżu Wschodniopomorskim [Zus.: Relationen zwischen dem frühmittelalterlichen Siedlungswesen und physiogeographischen Hauptelementen auf dem Ostpommerschen Küstengebiet], (w:) Studia archaeologica Pomeranica, red. F.J. Lachowicz, Koszalin, s. $189-214$

1976a Szczecin-Ustowo, stanowisko 1, „Informator Archeologiczny. Badania rok 1975”, Warszawa, s. $5 !-52$.

1976b Śmiardowo Krajeńskie, woj. pilskie, stanowisko I, „Informator Archeologiczny. Badania rok 1975", Warszawa, s. 52-53.

1979 Kru.szki, gm. Lobżenica, woj. pilskie, stanowisko I. „Informator Archeologiczny. Badania 1978”, Warszawa, s. 29.

1980 Dworzakowo, gm. Biatośliwie, woj. pilskie, stanowisko 2, „Informator Archeologiczny. Badania rok 1979", Warszawa, s. 27-28.

1981 Zagadnienie grupy ustowskiej (bricko-ustowskiej) kultury pucharów lejkowatych w Polsce [Sum.: Problems of the Ustowo Group of the TRB Culture], (w:) Kultura pucharów lejkowatych w Polsce. Studia i materialy, red. T. Wiślański, Poznań, s. 137-160.

1983a Środowisko fizyczno-geograficzne aglomeracji szczecinskiej, (w:) Dzieje Szczecina, t. I: Pradzieje Szczecina, red. W. Filipowiak, G. Labuda, Warszawa-Poznań, s. 42-58.

1983b Stosunki kulturowe u ujścia Odry w neolicie i w poczqtkach epoki brazu, (w:) Dzieje Szczecina, t. 1: Pradzieje Szczecina, red. W. Filipowiak, G. Labuda, Warszawa-Poznań, s. 103-278.

Żak J.

1983 Kazimierz Siuchniński, „Sprawozdania Archeologiczne” t. XXXIV, s. 301-303. 